\title{
LAW AND THE LAW SCHOOL IN THE TWENTY-FIRST CENTURY
}

\author{
Sir Ivor Richardson*
}

This article was presented as a lecture on "Capital Law School Day" organised by the New Zealand Institute of Advanced Legal Studies to mark the occasion of the centenary of the Faculty of Law, Victoria University of Wellington in 1999.

What was remarkable about our law faculty? First of all, it provided a comprehensive and wide-ranging curriculum. ... The underlying premise was that mastering purely juridical subjects required a fundamental knowledge of modern socio-economic and political processes, and, therefore, had to be part of a comprehensive curriculum which included all the social sciences. To me, the university was a temple of learning, the focal point of minds that were our national pride, a centre of youthful energy, passion and quest. ${ }^{1}$

\section{INTRODUCTION}

The general theme of today's seminar is how the law and the Law School should develop into the coming millennium. I propose considering the future of Victoria Law School by referring to its unique strengths and attributes and how these have led to successes in the past. From there I go on to look at some of the changes that have taken place and are taking place in our legal world.

In talking about Victoria's past, it is inevitable that I will concentrate to some extent on the time that I myself was at the Law School. This is simply because my knowledge of that time is greater and should not in any way be understood to detract from the achievements of the Law School during other periods.

\section{VICTORIA'S STRENGTHS AND ACHIEVEMENTS}

First, what are the particular strengths of our Law School? In 1886 Sir Robert Stout proclaimed that Wellington "is the seat of Parliament and the seat of the Court of Appeal.

* President, New Zealand Court of Appeal.

1 M Gorbachev Memoirs (Doubleday, New York, 1996) 53. 
This city might be prominent for its special attention to jurisprudence, to law, to political science, to history".

Wellington's assets are not limited to Parliament and the Court of Appeal. There are resources such as the National Library and Archives, the presence of foreign embassies and representatives of non-government organisations, the head offices of Government Departments such as Courts, Justice and the Treasury, and government agencies such as the Censor's Office and the Commerce Commission. Such things matter more to a Law School than most other university departments. They have helped make law one of the real strengths of Victoria University and should continue to do so in the future.

In looking at how well Victoria has capitalised on these strengths one could first examine activities within the Law School. But one should also look at the role that Victoria staff and students have played in the wider world of law, both during their time at the Law School and afterwards. A professional school has a distinct impact on the profession. The achievements and performance of its graduates and academic staff in the profession and in public affairs reflect at least to some extent the ethos of the Law School and the quality of legal education there.

The prominence of Victoria University alumni in the ranks of the judiciary and government is immediately apparent. For example, over half of the permanent Court of Appeal Judges - 11 out of 21 - and half the Chief Justices - three out of six - in the last 50 years have come from Victoria as students or staff. The same is true of two out of three lawyer Governors-General and two out of three lawyer Prime Ministers, as well as all but one of the Solicitors-General.

I can perhaps best illustrate the other numerous achievements of former Victorians by commenting on those who were on the academic staff at the Law School during my own time on the Faculty from 1967 to 1973.

Victoria has always been particularly strong in international law and in this field Victoria staff have been especially prominent. Professor Quentin Quentin-Baxter who took the second chair in the Department of Jurisprudence and Constitutional Law in 1968 following a career in Foreign Affairs, was elected to the International Law Commission in 1971 and in 1974 led New Zealand's legal challenge to French Pacific nuclear testing in the International Court of Justice. Professor Ken Keith, now my colleague on the Court of Appeal, took up a chair in 1973 during an eminent public and international law career. His involvement in international law continued and he went on to be President of the Law Commission. Colin Aikman, also at Foreign Affairs, preceded Quentin-Baxter and was another very prominent international lawyer and played a pioneering role in international human rights in the 1940s. He also played a large part in setting the Constitution of Samoa and went on to be foundation Vice Chancellor of the University of the South Pacific and 
then High Commissioner to India. Alison Quentin-Baxter was also on the Faculty and was much involved in the constitutional development of the Cook Islands, Niue and Fiji. Professor Tony Angelo pioneered comparative law in the Faculty (and on the side also at Monash) and played a leading role in the development of Pacific constitutions and in identifying and reforming the statute book of Mauritius.

Victorians not only led in international law. Professor George Barton, also an international lawyer, taught a range of subjects and launched legal history at Victoria. After serving as Dean, he went on to a very prominent career at the bar and may now rightly be regarded as the country's senior Queen's Counsel. Professor Mathieson launched industrial law and wrote the first major New Zealand text on that subject. He also went on to a very distinguished career at the bar. Professor Inglis, who whilst at Victoria wrote the first major New Zealand texts on family law and conflicts, went on to be President of the Wellington District Law Society and has played a prominent role in family law in New Zealand both as an academic and a judge. Peter MacKenzie also went to the bar and later chaired the Securities Commission as well as having substantial overseas law reform involvement through the Commonwealth Secretariat and other agencies. Professor I D Campbell was a stimulating lecturer and writer, as well as a major university administrator and Deputy Vice Chancellor. Finally, Professor Ellinger went on from Victoria to Monash and Singapore and is a major commercial law scholar. He co-authored Chitty on Contracts and Benjamin's Sale of Goods and is the author of a major Commonwealth text on banking law. He has also been an expert witness in many cases.

Amongst younger academic staff around that time were Lindsay McKay, Dr Robin Congreve and Richard Green who went on to become leading New Zealand tax lawyers; Professor Yuri Grbich and Professor Phillip Burgess, who are leading tax teachers and writers in Australia; and Brian Hanson, a tax academic and practitioner in various countries. Reflecting the strength of public law at Victoria, Professor Mullan is a leading figure in Canada, as Professor Roger Clark is in America. And Terence Arnold QC; the Victoria Chancellor, D J White QC; and Gerard Curry are now leading New Zealand practitioners. Also at the Faculty was Alex Frame, a man of many parts who wrote his LLM thesis in tax, authored an acclaimed book on Salmond, and has been involved within and outside government on constitutional questions and Treaty matters. Last but not least in what is by no means a complete list is my fellow speaker today, Sir Geoffrey Palmer. He became Professor in 1973 and returned to teach at the Faculty in 1991 after time off as Attorney-General and Prime Minister in between.

\section{OTHER CRITERIA}

I am not suggesting that the subsequent exploits of its staff is the only criteria by which to judge a law school. But one of the objectives of a law faculty should be to involve itself 
and its staff in the legal community. The links this gives the law school benefits it in the performance of its key functions.

The most important criteria by which to measure a law school are, I suggest, first the quality of its teaching: is the law school producing competent and ethical lawyers? And second the quality of its scholarship.

Lord Goff once commented that the work of judge and jurist are complementary: "it is the fusing of their work which begets the tough, adaptable system which is called the common law". First, judges and practitioners alike benefit from traditional legal scholarship: the careful enunciation of legal principles and what can be drawn from them that helps illuminate and inform the debate on a given legal issue. Second, most judges and practitioners do not have the time or resources to examine many of the wider social issues that may come to be argued by or before them. For empirical research and the development of legal scholarship informed by disciplines as diverse as economics, sociology and philosophy, judges should be able to depend on the work being done in law schools.

The courts are often said to be an inappropriate forum for determining broad policy issues. The adversarial process is not particularly suited to the conduct of an extended public interest inquiry. The parties may lack resources or any interest in exploring wider issues. And it is difficult for judges to be confident that their own reading and research is sufficient for a full appreciation of the economic and social implications of alternative approaches. Think about the long process of research, discussion and consultation that the Law Commission goes through before proposing a major change to our law, or the Parliamentary select committee process and research done by the relevant Ministry before legislation is drafted. Compare this with the court system where we are sometimes asked to make major policy decisions based on nothing more than legal theory.

Even so, the courts are required to make major policy decisions. It is sometimes unavoidable. When this is required, the problem lies not so much in an inherent inability on the part of the courts to assess economic and social data: lawyers are trained, or should be, to think through the consequences of legal decisions. The difficulty is ensuring that the relevant material is before the court and is utilised by the judge.

It is not hard to think of concrete examples of recent cases in the Court of Appeal where empirical data either was referred to or could have been were it available. In Aoraki Corporation $v$ McGavin ${ }^{2}$ the Court referred to extensive statistical evidence showing that four weeks or a month is the most common notice period in contracts containing

2 Aoraki Corporation v McGavin [1998] 3 NZLR 276 (CA). 
redundancy clauses. The Court observed that the general practice as to the period of notice was so clear that there could be no justification for fixing the period of notice, in the absence of a contractual stipulation, at much in excess of one month. The empirical evidence allowed the Court to set the notice period by reference to actual industry practice rather than assumptions about what might have been appropriate.

In $Z v Z_{r^{3}}$ the Court referred to a great deal of overseas material assembled by Terence Arnold as amicus, and to a lesser extent New Zealand material, demonstrating the effects of marital breakdown on women. Although in that case our judgment was limited by the legislation, this research was nevertheless relevant to spousal maintenance. It will also be relevant should Parliament reconsider the Matrimonial Property Act.

In Lange $v$ Atkinson, ${ }^{4}$ we were left to assume the detrimental effect defamation law has on the health of our democracy. There were no extensive reports or empirical studies demonstrating that the fear of libel awards actually inhibits freedom of the press. Interestingly, a recent overseas study provides that support.

Recently in Hamed Abdul Khaliq Al Ghambi Company $v$ New Zealand Dairy Board, ${ }^{5}$ the issue was whether the appropriate approach to the review of a Master's decision is de novo or appellate. Although the Court was given some limited statistics, a study analysing Masters' performance and the number of applications for review of Masters' decisions and the results would have assisted.

To give a final example, we are soon to hear a case in which one of the issues is drug testing in the workplace. Clearly empirical material on the nature and extent of the problem, the need for such testing for health and safety reasons, and the privacy impacts would be helpful.

I should say that there is some excellent empirical research being done. The pioneering work on the jury system recently undertaken by Professor Warren Young is a good example. It provides very valuable material on the functioning of juries and tests some of the assumptions underlying rules of evidence and criminal practice. Another good example is the Law Commission's pioneering study on who benefits under wills and intestacies. And the comprehensive survey of approaches to televising court proceedings in various jurisdictions by Western Australian academic Daniel Stepniak is another

3 Z v Z [1997] 2 NZLR 257 (CA).

4 Lange $v$ Atkinson [1998] 3 NZLR 424 (CA).

5 Hamed Abdul Khaliq Al Ghambi Company v New Zealand Dairy Board (24 March 1999) unreported, Court of Appeal, CA 110/98. 
example that comes to mind. But regrettably there is far too little empirical research to assist decision making by the courts.

What I have been saying is not intended to detract from the undoubted value of traditional legal scholarship. The formulation of legal doctrine is no easy task and demands the rigorous analytical skills that are found in law schools.

The growth of interdisciplinary studies will, I believe, be an important feature of legal education in the coming century. It is an area in which Victoria could lead the way. New Zealand law students already benefit greatly from a structure which permits most to do a double degree, usually by combining law with arts or commerce. Legal education should prepare students for a wide range of careers and not only for legal practice. The rigorous analytical skills taught in law schools are valued by employers in any number of industries and occupations outside traditional legal practice. A 1997 destinations survey of Auckland University graduates suggested that only about half of all law graduates were going on to traditional legal careers. And I would hazard a guess that a higher proportion of Victoria students have gone on to careers in government and the public sector than the graduates of other New Zealand law faculties. A multi-purpose education in law prepares students for careers in public service or business as well as the practice of law, and flexible curriculum that allows students to put together a degree from a wide range of elective subjects assists in this objective.

To summarise what has been said so far, our Law School should aim to play an active role in the wider legal community, to give students the skills they need for a broad range of careers, and to undertake original and valuable research. My impression is that Victoria has done this well in the past and can continue to do well in the future.

\section{LEGAL PRACTICE IN NEW ZEALAND}

The nature of the arguments being made in New Zealand courts and the authorities upon which the parties rely are changing. Just over 15 years ago I gave a talk entitled "Judicial Decision Making" at the Victorian Law Reform Commission in Melbourne. In preparing for that talk I examined the origin of the cases being cited in courts throughout the Commonwealth by taking samples from the various law reports. In volume one of the 1982 New Zealand Law Reports, 39 per cent of the cases cited were from New Zealand, 42 per cent were from the United Kingdom, 12 per cent were Australian and seven per cent were North American. I compared these figures with the cases cited in the Victorian Reports, where 58 per cent were Australian, 39 per cent from the United Kingdom and three per cent were from elsewhere. This represented a dramatic reversal from 30 years earlier in 1952 when 58 per cent of the cases cited were from the United Kingdom and 39 per cent were from Australia. Incidentally a look at the cases cited in the Victorian Reports in 1998 reveals that over 85 per cent of the cases there cited were Australian. In my earlier 
talk I noted also that in 1982, 80 per cent of the cases cited in the Canadian Western Weekly Reports were Canadian and 95 per cent of the cases cited in the House of Lords were from the United Kingdom. At the time I suggested that the pattern in New Zealand reflected the fact that we are a small society and that in many areas of law there are few if any appellate decisions of our own directly on point.

This has surely changed. The provenance of the cases being cited in the New Zealand courts today reveals two things. First, a substantial body of indigenous law has developed in many areas. In volume one of the New Zealand Law Reports for 1998, 50 per cent of the cases cited were of New Zealand origin. As I mentioned, in 1982 the figure was 39 per cent. Fifty years ago less than a third of the cases cited in the New Zealand Law Reports were of local origin and 100 years ago it was well under 20 per cent. Second, the nature of the overseas materials relied on is changing. In the same volume in 1998, three per cent of the cases were from the United Nations' Human Rights Committee and there were also three cases from the European Court of Human Rights. Judges often look at material from Australia, Canada and the United States; England is no longer the sole source of overseas material. New Zealand is increasingly searching out its own answers to social and legal problems, but in doing so we are willing to examine a wide range of approaches taken elsewhere. For this reason overseas authorities are still more frequently cited in New Zealand than in other comparable Commonwealth jurisdictions.

The vastly improved access to such materials as a result of the internet will, I suggest, result in even greater reference to them in the New Zealand courts. To give but a sampling, the internet gives instant access to decisions of the House of Lords and the English Court of Appeal, the High Court of Australia and most federal and State Court decisions, the Supreme Court of Canada and all Canadian Federal Court decisions, and all US Federal Courts of Appeal decisions as well as those of State Courts. In the case of the United States Supreme Court all decisions dating back to 1893 can be accessed on-line. A huge range of United Nations and other human rights materials are also available.

There is also a foreign influence by way of education. The nature of that education is changing. My impression is that more New Zealand law graduates now go on to masters degrees in the United States than in England. Certainly that was the case 30 years ago and the downstream result is manifesting itself in New Zealand legal practice. American educated lawyers are particularly prominent on the current Court of Appeal. Four of the seven permanent members of the Court have studied in the United States. Added to this is our new Chief Justice who is a graduate of Stanford. The increased impact of American law reflects the experiences of those who have returned to attain influential positions in New Zealand.

Other forces are also causing changes in legal practice. One is the globalisation of the economy. This both influences the nature of the disputes that come before the Court and 
leads the Court to consider the wider impact of its decisions, for example the benefits that flow from certainty and uniformity in international commercial law.

The development of international human rights law has had a substantial influence. Lawyers involved in the explosion of Bill of Rights cases in the early 1990s turned far more towards North America and international law sources for their precedents than towards England.

Things may change. Exciting legal developments in Europe including the introduction of the European Convention as the law of the United Kingdom and the devolution of powers to Scotland and Wales may draw New Zealand law graduates.

The preceding statistics and comments suggest that today's students must be equipped to seek out and read a wide range of foreign case law and international materials. Already New Zealand lawyers have the right to practise in Australia and vice-versa, and large international law firms regularly recruit in New Zealand. New Zealand's is a small economy, vulnerable to changes in world markets and international capital flows. In the future our business and political links with our neighbours, particularly Australia, are likely to increase and New Zealand lawyers should be prepared to function in this new environment.

\section{CONCLUSION}

Over the course of the 100 years for which Victoria University has existed, the size of the legal system, using that term in its broadest sense, has increased enormously. ${ }^{6}$ Whilst the pace of change was more leisurely for the first half of the century, it has been rapid since then.

There are various indicators of the size of the legal system. Three obvious indicators are the relative numbers of lawyers, prisoners and police officers. Between 1900 and 1960 the number of lawyers, the number of prisoners and the number of police officers all increased, very approximately, by a factor of four. These changes were not out of all proportion to changes in the population, which increased about three-fold from 808,100 in 1900 to $2,403,600$ in 1960 .

In 1960 there were 2,197 practising certificates issued around the country, 1,777 prisoners in our jails, and 2,436 police officers on the beat. In that year there were 15 Supreme Court judges and 36 Stipendiary Magistrates. After 1960, increases in these numbers were rapid. Since 1960 the number of lawyers has risen approximately four-fold to around 8,000, whereas the number of prisoners has increased by about 2.9 times to 5,152

6 See Appendix. 
(at the publication of the last Yearbook) and police numbers have increased by about 2.7 times to 6,492 equivalent full time sworn officers. The close correlation between police and prisoner numbers suggests that where police numbers go, rates of arrest and the flow on effects through the justice system will follow. As for judges, as well as the Chief Justice, there are now seven permanent members of the Court of Appeal, 30 High Court judges, five masters of the High Court, 116 District Court judges including six working in the Environment Court, eight Maori Land Court judges and four Employment Court judges. To put the increases in context, the population has increased by about 1.5 times since 1960 and GDP has tripled.

Rates of increase have been greatest towards the end of the century. In 1970 there were 2,750 practising certificates issued; in 1980 3,800; in 1990 5,900; and last year about 8,000. In 1998, there were 826 new admissions. This represented over 10 per cent of the number of practising lawyers in New Zealand, and indicates the likelihood of further increases. So over the last 20 years the membership of the legal profession has doubled, whilst the population has increased by just 20 per cent.

As discussed above, the increase in size has gone hand in hand with great changes in the nature of legal practice in New Zealand. I do not think that we live in an especially litigious society and the number of lawyers reflects more the broad range of work done by solicitors in New Zealand.

This centennial of our Law School is an opportunity to look back and reflect on the achievements of the past and is also an opportunity to look forward and consider how Victoria can excel in the legal environment of the future. In looking back we should ask ourselves how well Victoria has performed and why, and also ask what this tells us about Victoria's strengths and weaknesses. In looking forward the Law School should consider how it can capitalise on its strengths and ask itself what realistic goals should be set for the future. By taking stock and careful planning Victoria can ensure its continuance into the coming century as a truly capital Law School. 
APPENDIX

\begin{tabular}{|c|c|c|c|c|c|c|}
\hline & Judges & Lawyers* & Prisoners & Police & $\underline{\text { GDP }}$ & Population \\
\hline 1900 & $\begin{array}{l}6 \text { Supreme Ct } \\
29 \text { Magistrates }\end{array}$ & $\begin{array}{l}\text { Approx }= \\
400 \#\end{array}$ & 527 & 586 & & 808100 \\
\hline 1930 & 9 Supreme Ct & 1767 & 1523 & 1147 & $\begin{array}{l}1932=£ 114 \\
\text { million }\end{array}$ & 1506800 \\
\hline 1960 & $\begin{array}{l}15 \text { Supreme Ct } \\
36 \text { Magistrates }\end{array}$ & 2197 & 1777 & 2436 & $\begin{array}{l}\$ 36 \text { billion in } \\
1962 \\
\text { (91/92 prices) }\end{array}$ & 2403600 \\
\hline 1970 & $\begin{array}{l}17 \text { Supreme Ct } \\
42 \text { Magistrates }\end{array}$ & 2750 & 2365 & 2950 & $\begin{array}{l}\$ 49 \text { billion } \\
\text { (91/92 prices) }\end{array}$ & 2857900 \\
\hline 1980 & $\begin{array}{l}25 \text { High Ct } \\
68 \text { District Ct }\end{array}$ & 3800 & 2801 & 4758 & $\begin{array}{l}\$ 62 \text { billion } \\
\text { (91/92 prices) }\end{array}$ & 3144000 \\
\hline 1990 & $\begin{array}{l}38 \text { High Ct } \\
93 \text { District Ct }\end{array}$ & 5900 & 3318 & 5197 & $\begin{array}{l}\text { \$74 billion } \\
\text { (91/92 prices) }\end{array}$ & 3434950 \\
\hline 1999 & $\begin{array}{l}\text { Chief Justice } \\
7 \mathrm{Ct} \text { of Appeal } \\
30 \text { High Ct } \\
5 \text { Masters } \\
116 \text { Dis Ct } \\
\text { (including } 6 \\
\text { Environment Ct } \\
8 \text { Maori Land Ct } \\
4 \text { Employment } \\
\mathrm{Ct} \text { ) }\end{array}$ & 7985 & 5152 & $6492^{\circ}$ & $\begin{array}{l}\text { \$87 billion } \\
\text { (91/92 prices) } \\
(1997)\end{array}$ & 3807500 \\
\hline
\end{tabular}

* Number of practising certificates issued. A lawyer who moved districts and had a new practising certificate issued would be recorded twice.

\# The NZLS annual report records 203 certificates with five districts reporting in 1902, and 781 certificates with eight districts reporting in 1910. 400 seems a fair guess.

- $\quad$ The office of Traffic Officer in the Ministry of Transport was abolished in 1992 and officers were transferred to the Police. 
